\title{
THE EVALUATION OF ALTERNATIVE SOLUTIONS FOR THE HIGHWAY ROUTE E-763 BELGRADE - SOUTH ADRIATIC: A CASE STUDY OF SERBIA
}

\author{
Ljubo Marković, Ljiljana Milić Marković, Snežana Mitrović, Slobodan Stanarević
}

Preliminary communication

Designing road projects involves a complex decision-making process whose objectives should be the implementation of the road design and its utilization in the narrowest sense, but also the facilitation of mobility, economic development of the area and improvement of the quality of life in a wider sense. All of this requires the consideration and understanding of many problems multi-criterial in nature, and decision making with regard to technical components, environmental constraints and the impact on society. The main goal of this paper is to use a real example to explain the role and significance of multicriteria evaluation methods. The theoretical postulates of multi-criteria evaluation are presented (VIKOR method). Using multi-criteria evaluation methods ranking was carried out of the alternative solutions offered for the E-763 highway route Belgrade-South Adriatic (Požega-Boljare section). Ranking was carried out on the basis of 12 criteria which form the basis for evaluating each of the alternative solutions. The calculation was performed using the VIKOR program packages and an analysis of the results obtained was carried out.

Keywords: alternative solutions; criteria; highway route; multi-criteria evaluation; ranking; road design; VIKOR

Vrednovanje varijantnih rešenja trase autoputa E-763 Beograd - Južni Jadran: studija slučaja u Srbiji

Prethodno priopćenje

Projektiranje putova predstavlja složen proces donošenja odluka čiji osnovni cilj treba biti realizacija projekta puta i njegova eksploatacija u užem smislu, ali i omogućavanje mobilnosti, privrednog razvoja područja i poboljšanje kvaliteta života u širem smislu. Sve ovo zahtjeva sagledavanje i razumijevanje mnogih problema koji su višekriterijske prirode i donošenje odluka u vezi sa tehničkim komponentama, ograničenjima okruženja i utjecajima na društvo. Osnovni cilj rada je da se na realnom primjeru objasni uloga i značaj metoda višekriterijskog vrednovanja. Prezentirane su teorijske postavke višekriterijskog vrednovanja. Primjenom metode višekriterijskog vrednovanja (metoda VIKOR) izvršeno je rangiranje ponuđenih alternativnih rešenja trase autoputa E-763 Beograd-Južni Jadran (dionica Požega-Boljare). Rangiranje je izvršeno na osnovu 12 kriterija koji čine osnovu vrednovanja svakog alternativnog rešenja. Proračun je izveden primjenom programskog paketa VIKOR i izvršena je analiza dobivenih rezultata.

Ključne riječi: alternativno rješenje; kriteriji; projektiranje putova; rangiranje; trasa autoputa; višekriterijsko vrednovanje; VIKOR

\section{Introduction}

Road network is a part of the traffic network which performs a number of important tasks within the complete transport system (accommodating the projected level of traffic, economic and social development, mobility, environmental protection, functioning of the network in exceptional circumstances), aligning at the same time spatially and functionally with other transport subsystems (rail, air, transport, waterways) and complying with the set limits (use of the specified space, financial, technical and technological capabilities).

Designing roads, from identification of the project through choice of the route, implementation of the design and until its evaluation, is a long and complex process. Creating design solutions for roads in line with the functional requirements of traffic, environmental restrictions and maximum economic justification based on the real material potential of society is a multi-criteria task, the realization of which involves a multidisciplinary team of experts on the basis of their knowledge and creative skills (engineers, planners, economists and sociologists). The result of the planning and design process is a set of alternative solutions on the appropriate substrates. In order to choose the most suitable alternative and progress to the next stage of the project, the alternative solutions offered are subjected to the evaluation procedure.

\section{Evaluation of road design solutions}

Evaluation is the process of assessment that includes procedures for defining criteria (characteristics, i.e. the performance parameters of the alternatives) and indicators (real values for each criterion-monetary units, fuel consumption, levels of service, value assessment) relevant to the evaluation of the alternative solutions offered. A systematic and multidisciplinary approach plays an active role at all stages of a road design project.

Traditional methods of evaluation are based on the analysis of economic (financial) indicators of the project. There are various types of financial analysis, some of which are: Cost-benefit analysis (CBA) and Cost effectiveness analysis (CEA) [1]. CBA is often called socio-economic analysis of costs and benefits. CBA is most commonly used in cases where the funding for the project is provided by international monetary institutions or in the case of concessions. The unit used to measure these impacts is money $[2,3]$.

However, some impacts that cannot be valued in money (intangible values) can be left out of the quantitative analysis [4]. It is necessary later to qualitatively describe the impacts that cannot be expressed in money in a CBA in the best possible way. When it comes to new building or road reconstruction projects, there are also subjective criteria and objectives which are connected both to the decision-maker and the entire setting. The size of ratings that cannot be measured and which come with individual road project solutions (quality of life, aesthetic value, environmental pollution, emergency situations, etc.) are different for different groups of people. It is impossible to translate them into a common denominator. In their studies, some researchers $[5,6]$ have indicated the possibility of comparing the quantitative and qualitative aspects of potential alternatives using the multi-criteria evaluation, that is, by 
using the appropriate methods of multi-criteria analysis. In this way, the possibility was created to analyse multiple and conflicting problems, which is a great advantage of multi-criteria evaluation in the decision-making process [4].

\subsection{Multi-criteria evaluation}

Multi-criteria evaluation is an inseparable part of the design process. In terms of its role and function in designing roads, multi-criteria evaluation is characterized by the following features:

- multiple criteria - every problem has multiple criteria that may be the objective functions or the attributes;

- the mutual conflict of criteria - multiple criteria often conflict with each other;

- incommensurable units - the criteria are expressed in a variety of qualitative and quantitative units of measurement;

- $\quad$ project design/selection - the solutions for the multicriteria evaluation of a problem are either the design of the best alternative (there may be more than one of them) or selection of the best final alternative among those previously defined [7].

Within the framework of multi-criteria evaluation there are two different categories: multi-target evaluation (MTE), with its subgroup multi-target programming, and multi-attribute evaluation (MAE). With this in mind, the concept of multi-criteria evaluation in this paper will refer to multi-attribute evaluation (MAE).

\subsubsection{Models of multi-criteria evaluation}

A typical problem of multi-criteria evaluation can be mathematically presented in the following way:

(MAE) $\left\{\begin{array}{c}\text { Select } A_{1}, A_{2}, \ldots, A_{m} \\ \text { s.t. } K_{1}, K_{2}, \ldots, K_{n}\end{array}\right\}$.

Selection is based on maximizing the multi-criteria value functions (or benefits) presented by the interested parties. The basic information can be presented with the help of the matrix:

$$
\begin{aligned}
& K=\left(K_{1}, K_{2}, \ldots, K_{n}\right) \\
& \boldsymbol{D}=\begin{array}{c}
A_{1} \\
A_{2} \\
\vdots \\
A_{m}
\end{array}\left[\begin{array}{cccc}
x_{11} & x_{12} & \cdots & x_{1 n} \\
x_{21} & x_{22} & \cdots & x_{2 n} \\
\vdots & \vdots & \vdots & \vdots \\
x_{m 1} & x_{m 2} & \cdots & x_{m n}
\end{array}\right] \text {, } \\
& W=\left[w_{1}, w_{2}, \ldots, w_{n}\right]
\end{aligned}
$$

where: $A=\left(A_{1}, A_{2}, \ldots, A_{m}\right)-m$ are the alternatives between which the decision makers choose, $K=\left(K_{1}, K_{2}\right.$, $\left.\ldots, K_{n}\right)-n$ are the criteria by which the performance is measured, $x_{i j}, i=1, \ldots, m ; j=1, \ldots, n ;$ - are the ratings of alternative $A_{i}$ taking into account criterion $K_{j}, w_{j}-$ is the weighting factor of criterion $K_{j}$.

In multi-criteria evaluation the basic problem is to determine the importance and weights of the criteria.
Determining the importance of the criteria is a subjective action in which a system of values is interpreted in a specific task of multi-criteria evaluation. The importance of the criteria is expressed by coefficients of their relative weights: to each criterion $k \in K$ a relative weight $w_{k}, k=$ $1,2, \ldots, K$ is attached. Different methods are used for determining the weight of the criteria (minimum mean square error method, the Eigenvector method, the entropy method and methods using the collective evaluation of a group of experts: the ranking method, the rating method (evaluation) and the method of pair-wise comparison). In the most simple case, each $w_{k}$ is a no negative number, and if $\Sigma w_{k}=1$, it is said that the relative weights of the criteria are normalized. The different treatment of the weights of the criteria by a variety of methods is most effective when solving multi-criteria problems in which there are only a few alternatives, while differences in the final ranking of the variants when using different methods are characteristic for the problems that include several alternatives. Also, the influence of the distribution of the weights of the criteria differs for different methods of multi-criteria evaluation [8].

Depending on the nature of each specific problem of multi-criteria evaluation, there are three possible basic approaches to its solution:

- the problem of ranking - the set of all alternatives is ranked (action, nodes, project designs) from "the best" to "the worst";

- the problem of choosing one alternative - it is necessary to select the "best" alternative;

- the problem of choosing more alternatives - more alternatives are chosen when:

- starting with the highest rank, a predefined number of alternatives is adopted,

- a selection is made of those alternatives which meet certain other conditions that are not incorporated in the initial model of multi-criteria values [9].

\subsubsection{Multi-criteria evaluation methods}

There are a number of different methods of multicriteria evaluation present in the relevant literature. These methods can be categorized in different ways, e.g. according to the shape of the model (e.g. linear, nonlinear, stochastic), according to the spatial characteristics (e.g. finite or infinite), or the alternatives presented (e.g. prespecified preferences (possibilities) or interactive) [10]. The Analytic Hierarchy Process (AHP) is one of the most commonly used methods in the field of transportation and it is presented in a study by [11] and in various other papers [4, 12]. In addition, there are also the following methods: PROMETHEE [13], SAW [14], TOPSIS [15] $[16,17]$, ELECTRE [18], MAVT [19], VIKOR [20].

All of these methods have taken a significant place in the process of evaluating the alternative offered as an aid to decision making. The selection of which method to use for multi-criteria evaluation depends, above all, on the nature of the multi-criteria problem [21], but also on the aspirations of the decision maker, and his/her familiarity with the available methods. 


\subsubsection{The VIKOR method (Multi-criteria Compromise Ranking)}

The VIKOR method and its software package (VIKOR) solve optimization tasks which have a number of heterogeneous and conflicting criteria. The resulting solution is a compromise and can be unique or represent a set of close solutions. The compromise solution is the allowable solution which is closest to the ideal. The ideal solution is determined on the basis of the best criteria values and is usually not found in the given set of alternative solutions [22].

The VIKOR method algorithm

It is necessary to carry out ranking of alternative solutions $a_{1}, a_{2}, \ldots, a_{j}$ with the given values of the criterion functions $f_{i j}, i=1, n$ and $j=1, J$, where $n$ is the number of criteria, and $J$ is the number of alternatives. The ranking procedure is as follows [20]:

a) The best $f_{i}^{*}$ and the worst $f_{i}^{-}$values for all criterion functions $i=1,2, \ldots, n$ are determined:

$f_{i}^{*}=\max _{j} f_{i j}, f_{i}^{-}=\min _{j} f_{i j}$, if the $i^{\text {th }}$ function represents the profit,

$f_{i}^{*}=\min _{j} f_{i j}, f_{i}^{-}=\max _{j} f_{i j}$, if the $i^{\text {th }}$ function represents the cost.

b) On the basis of the measures $S_{j}$ and $R_{j}$ ranking of alternative solutions is carried out and the place of alternative $a_{j}$ is determined on the rank lists $s\left(a_{j}\right)$ and $r\left(a_{j}\right)$, whereas the values of $S_{j}$ and $R_{j}, j=1,2, \ldots, J$ are calculated using the relation:

$$
\begin{aligned}
& S_{j}=\sum_{i=1}^{n} \omega_{i}\left(f_{i}^{*}-f_{i j}\right) /\left(f_{i}^{*}-f_{j}^{-}\right) \quad(\text { for } p=1), \\
& R_{j}=\max _{i} \omega_{i}\left(f_{i}^{*}-f_{i j}\right) /\left(f_{i}^{*}-f_{j}^{-}\right) \quad(\text { for } p=\infty),
\end{aligned}
$$

where: $n$ - is the number of criteria, $\omega_{i}$ - is the weight of the $i^{\text {th }}$ criterion and it expresses the preference of the decision maker, i.e. the relative importance of the criterion; $S_{j}$ - is the measure of distance $R(F, 1)$ from the ideal point for alternative $j ; R_{j}$ - is the measure of distance $R(F, \infty)$ from the ideal point for alternative $j$.

By ranking according to the measures $S_{j}$ and $R_{j}$ two rank lists of alternatives are obtained. In order to obtain a unified rank list, compromise programming is used, by means of which $S_{j}$ and $R_{j}$ are now criterion functions. The new measure for ranking is:

$$
Q_{j}=v Q S_{j}+(1-v) Q R_{j}=v \frac{S_{j}-S^{*}}{S^{-}-S^{*}}+(1-v) \frac{R_{j}-R^{*}}{R^{-}-R^{*}}
$$

where: $S^{-}=\max _{j} S_{j}$ and $R^{-}=\max _{j} R_{j} ; v=\frac{n+1}{2 n}$ is the weight of the decision-making strategy for the group benefit; $(1-v)$ is the weight of individual dissatisfaction.

$Q S_{j}$ and $Q R_{j}$ represent the normalized values. Alternative $a_{j}$ is a better multi-criteria alternative than alternative $a_{k}$, if $Q_{j}<Q_{k}$ and it has a higher position on the rank list.

c) The VIKOR method proposes as the best multicriteria alternative the one which is in the first place on the compromise rank list for $v=0.5$ only if it has:

- $(\mathrm{C} 1)$ - "sufficient advantage" over the alternatives in the next position. For evaluating the "advantages", the difference with measure $Q_{j}$ is used. Alternative $a^{\prime}$ has sufficient advantage over the other items on the rank list $a^{\prime \prime}$ if:

$Q\left(a^{\prime \prime}\right)-Q\left(a^{\prime}\right) \geq D Q$

where $D Q$ is the "advantage threshold". There is a limited threshold at 0.25 for cases with a small number of alternatives

$D Q=\min \left(0,25 ; \frac{1}{(J-1)}\right)$

- $\quad(\mathrm{C} 2)$ - a "stable enough" first position with a change of weight $v$ (for $v=0.25$ and $v=0.75$ ). Alternative $a^{\prime}$ must also be the best ranked using $Q S$ and/or $Q R$.

If any of the conditions is not met, a set of compromise solutions is formed in which the first alternative and the one after it are included. If the only condition that the first alternative does not fulfil is (C2), then only the second item on the compromise rank list enters the set of compromise solutions. If it does not meet the condition $(\mathrm{C} 1)$, then the set of compromise solutions contains the alternatives from the compromise rank list until the one which fulfils the condition that the first alternative does not have sufficient advantage over.

The results of the VIKOR method are:

- a rank list according to measures $Q R, Q$ (for $v=0.5$ ) and $Q S$;

- a compromise alternative or a set of compromise solutions.

These results are the basis for decision making and adopting the best (multi-criteria optimal) solutions [20].

\section{Case Study in Serbia-a presentation of the evaluation of alternative solutions offered 3.1 Case Analysis}

Within the General Design of E-763 highway Belgrade-South Adriatic for the part from Požega to the Montenegro border (Boljare), and in accordance with the 1996 Spatial Plan of the Republic of Serbia, four alternative solutions have been designed: West; Centre; East 1 and East 2 (Fig. 1). Realization (construction and exploitation) of each of the analysed alternative solutions has a consequence in a number of direct and indirect as well as positive and negative effects. The purpose of multi-criteria analysis application is to identify the most significant effects for each alternative, to use them as evaluation criteria in order to minimize negative and maximize positive effects, and based on the results of application of a chosen method to rank variants and give a proposal to the investor as to which variant of highway 
corridor is the most acceptable for further elaboration of the required study-technical documentation.

When evaluating and ranking the variants the results were used of some parts of the General Design and studies as follows: Route design (investment-building and spatial aspect), Traffic study (traffic and economic aspect) and Study of environmental influence [23]. The main technical and exploitation characteristics of the considered design solutions for the highway and the values of predicted traffic flows are shown in Tab. 1 and Tab. 2 respectively.

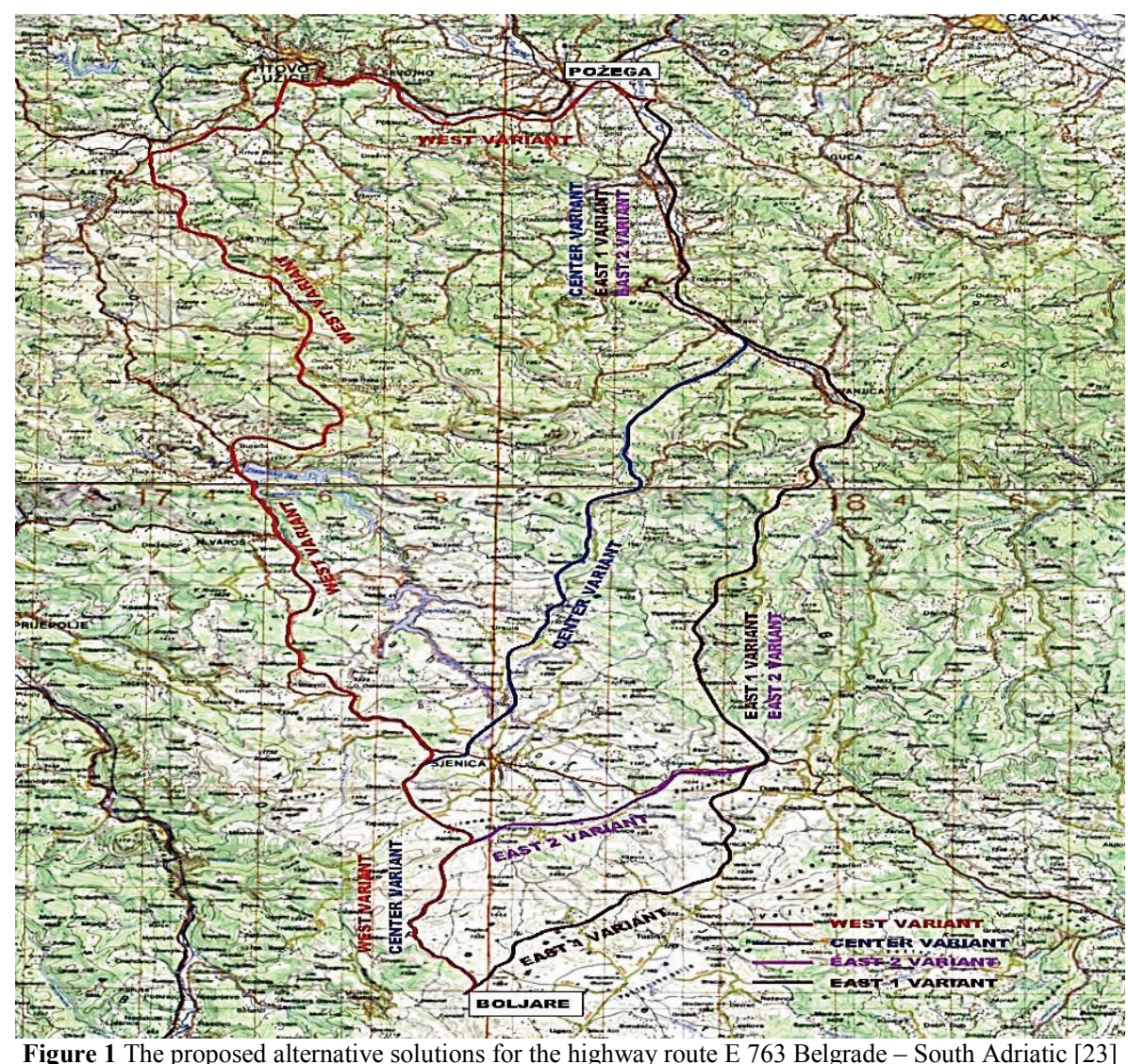

Table 1Technical characteristics of highway route alternative solutions [23]

\begin{tabular}{|c|c|c|c|c|c|c|c|}
\hline E 763, Sector III, & \multicolumn{7}{|c|}{ Alternative } \\
\hline Požega - Montengro border & \multicolumn{2}{|c|}{ West } & \multicolumn{2}{|c|}{ Centre } & East 1 & \multicolumn{2}{|c|}{ East 2} \\
\hline Total route length $(\mathrm{km})$ & & & & & 106,81 & & \\
\hline Design speed $(\mathrm{km} / \mathrm{h})$ & 120 & 100 & 120 & 100 & 120 & 120 & 100 \\
\hline $\begin{array}{l}\text { Length of variant per sections, depending on } \\
\text { the design } \operatorname{speed}(\mathrm{km} / \mathrm{h})\end{array}$ & 26,51 & 115,27 & 41,31 & 60,05 & 106,81 & 92,81 & 18,30 \\
\hline Number of traffic lanes per direction & 2 & 2 & 2 & 2 & 2 & 2 & 2 \\
\hline Traffic lane width (m) & 3,75 & 3,5 & 3,75 & 3,5 & 3,75 & 3,75 & 3,5 \\
\hline Emergency stopping lane width (m) & 2,5 & 2,5 & 2,5 & 2,5 & 2,5 & 2,5 & 2,5 \\
\hline Min. radius of horizontal curve $(\mathrm{m})$ & 750 & 450 & 750 & 450 & 750 & 750 & 450 \\
\hline $\begin{array}{l}\text { Average gradient along the entire section } \\
\text { length (\%) }\end{array}$ & 2,51 & 3,60 & 2,06 & 3,13 & 2,60 & 2,57 & 2,81 \\
\hline
\end{tabular}

Table 2 Exploitation characteristics of highway route alternative solutions [23]

\begin{tabular}{|c|c|c|c|c|c|c|}
\hline \multirow{2}{*}{\multicolumn{2}{|c|}{$\begin{array}{c}\text { E } 763, \text { Sector III, } \\
\text { Požega - Montenegro border }\end{array}$}} & \multicolumn{5}{|c|}{ Alternative } \\
\hline & & Base & West & Centre & East 1 & East 2 \\
\hline \multicolumn{2}{|c|}{ Average exploitation speed $(\mathrm{km} / \mathrm{h})$} & 67,95 & 77,44 & 78,51 & 77,52 & 77,61 \\
\hline \multicolumn{2}{|c|}{ Total annual travelling time $(\mathrm{h})$} & 12.540 .142 & 8.560 .500 & 4.328 .764 & 4.575 .486 & 4.603 .352 \\
\hline \multirow{2}{*}{$\begin{array}{c}\text { Traffic } \\
\text { (PGDS) }\end{array}$} & I year & \multirow{2}{*}{3.645} & 6.437 & 5.032 & 4.995 & 4.973 \\
\hline & XX year & & 12.498 & 9.769 & 9.697 & 9.654 \\
\hline \multicolumn{2}{|c|}{ Annual exploitation costs $(€)$} & 254.211 .451 & 333.385 .201 & 204.895 .959 & 213.962 .676 & 220.675 .256 \\
\hline \multicolumn{2}{|c|}{ Annual accident-related costs $(€)$} & 431.181 & 344.945 & 221.960 & 232.110 & 240.707 \\
\hline \multicolumn{2}{|c|}{ Fuel consumption (annual) } & 61.108 .840 & 88.856 .893 & 54.745 .814 & 57.166 .720 & 58.964 .572 \\
\hline \multicolumn{2}{|c|}{$\begin{array}{l}\text { Investment value } \\
\text { (per km of highway) }\left(10^{6} €\right)\end{array}$} & & 20,132 & 18,073 & 17,367 & 18,413 \\
\hline \multicolumn{2}{|c|}{ Annual maintenance costs $(€)$} & $\begin{array}{c}1 \%-2 \% \text { of } \\
\text { investment value }\end{array}$ & 34.960 & 26.784 & 28.140 & 29.464 \\
\hline
\end{tabular}




\subsection{Goals, criteria and evaluation indicators 3.2.1 Defining the goals of the evaluation}

The most important goals of building the PožegaBoljare highway are:

- increasing the level of service for the projected traffic flows on the road network in the corridor of the planned highway;

- improving the traffic safety level of the projected traffic flows on the road network in the corridor of the planned highway;
- reducing the user exploitation costs for the projected traffic flows on the road network in the corridor of the planned highway;

- facilitating the optimal access of high capacity and quality roads for the existing settlements, functional units and road networks;

- maximum preservation of the environment in the corridor of the planned highway;

- $\quad$ enabling faster development of the catchment area.

Table 3 Selected criteria and relevant indicators

\begin{tabular}{|c|c|c|}
\hline Criteria & & Indicators \\
\hline Construction investment costs & 浔 & $\begin{array}{l}\text { Previous and preparatory works; Substructure; Drains and drainage; Superstructure; } \\
\text { Multi-level intersections; Facilities for environmental protection; Relocation of roads and } \\
\text { other installations; Accompanying contents; Traffic signs and equipment. }\end{array}$ \\
\hline Operational cost to the user & 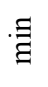 & $\begin{array}{l}\text { Fuel costs; Lubricant costs; Cost of pneumatics; Maintenance and repair costs; Additional } \\
\text { costs; Time dependent expenses (depreciation, interest, utility costs, salary of driver). }\end{array}$ \\
\hline Maintenance costs & $\cdot \Xi$ & $\begin{array}{l}\text { Length }(\mathrm{km}) \text {. } \\
\text { Cost of maintenance (regular, winter and increased due to the condition of the terrain). }\end{array}$ \\
\hline Total cost of traffic accidents & 刍 & $\begin{array}{l}\text { The number of accidents (number of fatalities, number of casualties, material damage). } \\
\text { The consequences of accidents (number of fatalities, number of casualties, material damage). }\end{array}$ \\
\hline Travel time & $\cdot \Xi$ & Length $(\mathrm{km})$; Longitudinal gradient $(\%)$; Speed $(\mathrm{km} / \mathrm{h})$. \\
\hline $\begin{array}{l}\text { Clash of the highway alternatives } \\
\text { with settlements }\end{array}$ & き & Arable land; Forest; Urbanized areas; Meadows and pastures; Orchards and vineyards. \\
\hline $\begin{array}{l}\text { Spatial conflict with the existing } \\
\text { land use }\end{array}$ & 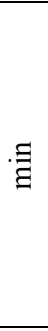 & $\begin{array}{l}\text { Relationship between the HW corridor and residential areas - the corridor passes at } 100-300 \mathrm{~m} \\
\text { from a settlement; the corridor passes at a distance of up to } 100 \mathrm{~m} \text { and touches a settlement; the } \\
\text { corridor passes through most of a settlement; } \\
\text { Relationship between the HW corridor and industrial zones - the corridor passes at } 100-300 \mathrm{~m} \\
\text { from an industrial zone; the corridor passes at a distance of up to } 100 \mathrm{~m} \text { from an industrial } \\
\text { zone; the corridor passes through most of an industrial zone; } \\
\text { Relationship between the HW route and the existing structure of land use - the corridor passes } \\
\text { through meadows and pastures; the corridor passes through forest, orchards, vineyards and } \\
\text { arable land; the corridor passes through a settlement. }\end{array}$ \\
\hline $\begin{array}{l}\text { Degradation of future } \\
\text { possibilities for spatial planning }\end{array}$ & き & $\begin{array}{l}\text { The corridor restricts further development and cuts through a settlement; the corridor passes at } \\
\text { a distance of less than } 500 \mathrm{~m} \text { from a settlement and partially restricts its further development; } \\
\text { the corridor passes at a distance greater than } 500 \mathrm{~m} \text { and does not restrict further development. }\end{array}$ \\
\hline $\begin{array}{l}\text { Functionality of connecting } \\
\text { spatial units and the activation of } \\
\text { development potential }\end{array}$ & 层 & $\begin{array}{l}\text { Functional connectivity of settlements: the corridor connects } 6 \text { or more settlements (municipal } \\
\text { centres); the corridor connects up to } 5 \text { settlements (municipal centres). } \\
\text { The possibility of activating the potential for tourism: the corridor connects a greater number } \\
\text { of zones and localities; the corridor connects a smaller number of zones and localities; the } \\
\text { corridor does not connect any tourist zones and localities. }\end{array}$ \\
\hline $\begin{array}{l}\text { The risk of destruction or } \\
\text { degradation of cultural and } \\
\text { natural heritage }\end{array}$ & き & $\begin{array}{l}\text { Monuments and archaeological sites in the impact zone. } \\
\text { Protected natural areas in the impact zone. }\end{array}$ \\
\hline $\begin{array}{l}\text { Relationship with environmental } \\
\text { consequences }\end{array}$ & き & $\begin{array}{l}\text { Noise - the length of the route through a settlement }(\mathrm{km}) \text {, the route touches a settlement and } \\
\text { the settlement is in the impact zone }(\mathrm{km}) \text {, the length of the route where there are settlements } \\
\text { outside the impact zone and the route goes through a tunnel }(\mathrm{km}) \text {. } \\
\text { Air pollution - the length of the route through settlements and forest }(\mathrm{km}) \text {, the length of the } \\
\text { route through agricultural land }(\mathrm{km}) \text {, other }(\mathrm{km}) \text {. } \\
\text { Water courses in the impact zone, water power facilities in the impact zone. } \\
\text { Soil pollution - length of the route through orchards, vineyards and agricultural land }(\mathrm{km}) \text {, } \\
\text { length of the route through forest }(\mathrm{km}) \text {, length of the route through settlements and other }(\mathrm{km}) \text {; } \\
\text { Flora and fauna - length of the route through forest }(\mathrm{km}) \text {, length of the route through } \\
\text { meadows, pastures and agricultural land }(\mathrm{km}) \text {, length of the route through settlements and } \\
\text { other }(\mathrm{km}) ; \\
\text { Vibration - monuments and archaeological sites in the impact zone, length of the route } \\
\text { through settlements }(\mathrm{km}) \text {, other }(\mathrm{km}) \text {. }\end{array}$ \\
\hline $\begin{array}{l}\text { Impact on the development of } \\
\text { society and indirect economic } \\
\text { effects }\end{array}$ & 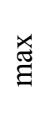 & $\begin{array}{l}\text { Development of tourism; Development of agriculture; Changes in the structure of } \\
\text { employment; Increase in the renting potential of the land; Changes in property value } \\
\text { Stop the outflow of the population; Increase in the quality of life. }\end{array}$ \\
\hline
\end{tabular}




\subsubsection{Selection of criteria and evaluation indicators}

Multi-criteria evaluation of the alternative project solutions involves consideration from various aspects: investment and construction, traffic and exploitation (operation), spatial and urban, environmental and socioeconomic. On the basis of this, criteria were chosen on which multi-criteria evaluation and ranking of the offered alternatives were based. The chosen criteria were developed through appropriate indicators. Tab. 3 shows the chosen criteria and the relevant indicators.

In Tab. 4, based on [23], for the given criteria the values have been calculated for all evaluation indicators and they are shown in the form suitable to carry out the predicted procedures of multi-criteria evaluation.

Table 4 Comparative presentation of the indicators for each route

\begin{tabular}{|c|c|c|c|c|c|c|}
\hline & \multirow{3}{*}{\multicolumn{2}{|c|}{ Indicator }} & \multicolumn{4}{|c|}{ Highway Route } \\
\hline & & & West & Centre & East 1 & East2 \\
\hline & & & \multicolumn{4}{|c|}{ The calculated indicator values } \\
\hline (1) & \multirow{4}{*}{$€$} & $\min$. & 2854412000 & 1830858000 & 1854867000 & 2045642000 \\
\hline (2) & & $\min$. & 333853201 & 204859959 & 213962676 & 220675256 \\
\hline (3) & & $\min$. & 2796815 & 2142738 & 2251236 & 2357113 \\
\hline$(4)$ & & $\min$. & 344945 & 221960 & 232110 & 240707 \\
\hline (5) & $\mathrm{h}$ & $\min$. & 8560501 & 4328764 & 4515483 & 4603952 \\
\hline (6) & $\mathrm{km}$ & $\min$. & 9.36 & 1.33 & 3.43 & 2.46 \\
\hline (7) & \multirow{6}{*}{$\begin{array}{l}\text { : } \\
\text { : } \\
\text { : }\end{array}$} & $\min$. & 8.46 & 2.73 & 4.07 & 3.77 \\
\hline (8) & & $\min$. & 0.32 & 0.41 & 4.76 & 4.76 \\
\hline$(9)$ & & $\max$. & 0.54 & 1.56 & 1.14 & 1.14 \\
\hline (10) & & $\min$. & 22 & 15 & 15 & 19 \\
\hline (11) & & min. & 177.455 & 116.043 & 133.792 & 138.474 \\
\hline (12) & & $\max$. & 35 & 45 & 52 & 53 \\
\hline
\end{tabular}

\subsection{Determining the relative weights of the criteria $\left(w_{i}\right)$}

The relative weights of the defined criteria of multicriteria evaluation were established by means of expert assessment. A simplified Delphi method was applied. A total of 56 participants ( 24 experts and 32 representatives from 7 municipalities in the catchment area) were surveyed. The surveys were conducted using questionnaires. On the basis of the results of a statistical analysis carried out on the participant's responses to the survey [23] the final results, that is, the relative weights of individual criteria (seen in Tab. 5) were presented.

\begin{tabular}{|c|c|c|c|c|}
\hline CRITERION & $\begin{array}{l}\text { Weight } \\
\text { of criterion }\end{array}$ & $\begin{array}{c}W \\
\text { Professionals } \\
\text { (experts) }\end{array}$ & $\begin{array}{c}W \\
\text { Residents } \\
\text { from the area }\end{array}$ & $\begin{array}{c}W \\
\text { MEDIAN } \\
\text { VALUE }\end{array}$ \\
\hline Construction investment costs & $\mathrm{W}_{1}$ & 0.12 & 0.11 & 0.11 \\
\hline Operational cost to the user & $\mathrm{W}_{2}$ & 0.09 & 0.08 & 0.08 \\
\hline Maintenance costs & $\mathrm{W}_{3}$ & 0.08 & 0.08 & 0.08 \\
\hline Total cost of traffic accidents & $\mathrm{W}_{4}$ & 0.14 & 0.10 & 0.11 \\
\hline Travel time & $\mathrm{W}_{5}$ & 0.11 & 0.09 & 0.10 \\
\hline Clash of the highway alternatives with settlements & $\mathrm{W}_{6}$ & 0.05 & 0.07 & 0.06 \\
\hline Spatial conflict with the existing land use & $\mathrm{W}_{7}$ & 0.05 & 0.06 & 0.06 \\
\hline Degradation of future possibilities for spatial planning & $\mathrm{W}_{8}$ & 0.06 & 0.11 & 0.09 \\
\hline $\begin{array}{l}\text { Functionality of connecting spatial units and the activation of } \\
\text { development potential }\end{array}$ & $\mathrm{W}_{9}$ & 0.04 & 0.05 & 0.04 \\
\hline The risk of destruction or degradation of cultural and natural heritage & $\mathrm{W}_{10}$ & 0.07 & 0.07 & 0.07 \\
\hline Relationship with environmental consequences & $\mathrm{W}_{11}$ & 0.10 & 0.11 & 0.11 \\
\hline Impact on the development of society and indirect economic effects & $\mathrm{W}_{12}$ & 0.08 & 0.07 & 0.08 \\
\hline
\end{tabular}

\subsection{Results of ranking-selection of the best alternative route solution using the VIKOR method}

Based on the established methodology of a comparative presentation of the criteria and their indicators with their corresponding relative weights using the VIKOR method the following results were obtained: a rank list of the alternative solutions according to individual criteria (Tab. 6) and a rank list according to $Q R$ - minimax strategy; $Q$ - compromise and $Q S$ - majority benefit (Tab. 7).
Based on the results of the evaluation using the VIKOR method based on the presented criteria (Tab. 6) and the rank list according to measures $Q R, Q$ and $Q S$ (Tab. 7), we can conclude that the Centre alternative route solution is the most favourable and it has a sufficiently stable first position. The advantage of this alternative solution in relation to the one that follows it (East 1) is $0.442(44.2 \%)$. 
Table 6 Results of multi-criteria ranking: Rank list according to individual criteria

\begin{tabular}{|c|c|c|c|c|c|c|c|}
\hline & \multirow{2}{*}{ Criteria } & & \multirow{2}{*}{$W_{i}$} & \multicolumn{4}{|c|}{ Highway route } \\
\hline & & & & West & Centre & East 1 & East 2 \\
\hline 1 & Construction investment costs & $\min$ & 0.11 & 4 & 1 & 2 & 3 \\
\hline 2 & Operational cost to the user & $\min$ & 0.08 & 4 & 1 & 2 & 3 \\
\hline 3 & Maintenance costs & $\min$ & 0.08 & 4 & 1 & 2 & 3 \\
\hline 4 & Total cost of traffic accidents & $\min$ & 0.11 & 4 & 1 & 2 & 3 \\
\hline 5 & Travel time & $\min$ & 0.10 & 4 & 1 & 2 & 3 \\
\hline 6 & Clash of the highway alternatives with settlements & $\min$ & 0.06 & 4 & 1 & 3 & 2 \\
\hline 7 & Spatial conflict with the existing land use & $\min$ & 0.06 & 4 & 1 & 3 & 2 \\
\hline 8 & Degradation of future possibilities for spatial planning & $\min$ & 0.09 & 1 & 2 & 3 & 4 \\
\hline 9 & $\begin{array}{l}\text { Functionality of connecting spatial units and the } \\
\text { activation of development potential }\end{array}$ & $\max$ & 0.04 & 4 & 1 & 2 & 3 \\
\hline 10 & The risk of destruction or degradation of cultural and natural heritage & $\min$ & 0.07 & 4 & 1 & 2 & 3 \\
\hline 11 & Relationship with environmental consequences & $\min$ & 0.11 & 4 & 1 & 2 & 3 \\
\hline 12 & Impact on the development of society and indirect economic effects & $\max$ & 0.08 & 4 & 3 & 2 & 1 \\
\hline
\end{tabular}

Table 7 Results of multi-criteria ranking: Rank list by measures

\begin{tabular}{|c|c|c|c|c|}
\hline \multirow{2}{*}{ Highway route } & \multicolumn{3}{|c|}{ Rank list by measures } \\
\cline { 3 - 5 } & \multirow{2}{*}{1} & QR & Q & QS \\
\hline 2 & CENTER & 0.036 & 0.000 & 0.038 \\
\hline 3 & EAST 1 & 0.091 & 0.442 & 0.210 \\
\hline 4 & EAST 2 & 0.091 & 0.493 & 0.291 \\
\hline
\end{tabular}

\section{Conclusion}

Key steps in the process of road design projects are creating alternative solutions, their evaluation and making a decision regarding the best solution, that is, a decision on the elements which are a prerequisite for transition to the next phase of the project. An effective approach to the process of evaluation is essential to improving the quality of decision-making.

In this paper the problem of determining the best alternative solution for the route for the General plan for the E 763 highway Belgrade-South Adriatic was analysed using a multi-criteria evaluation method (VIKOR method). In multi-criteria evaluation methods the goals are defined, and the criteria, their indicators and their weights are determined. Evaluation of the proposed alternative solutions was carried out by the VIKOR method. The results showed that the alternative Centre was the most favourable solution for the corridor route for the E763 Belgrade-South Adriatic highway.

Despite their indisputable quality, it should be noted that the effectiveness of that method, in the process of decision making depends to a great extent on the abilities and experience of the decision maker. The decision maker must be able to determine the importance of each criterion. This highlights in particular the significance of unbiased definition of the weight coefficients for individual criteria, since the chosen solution most often is not equally acceptable to the investors, the local community and other interested parties. A potential shortcoming of this approach is manifested in the fact that the interested parties can have different attitudes regarding the relative relationship between the chosen criteria, therefore the application of different methods makes it possible to have insight into the quality of the chosen alternative.

If the previous conditions are fulfilled, the VIKOR method becomes a powerful tool in the hands of decision makers that provides strong support to the process of solving complex problems of multi-criteria decision making.

\section{References}

[1] Department for Communities and Local Government. Multi-criteria Analysis: A Manual. Communities and Local Government Publications, London, 2009.

[2] U. S. Department of Transportation. Benefit-Cost Analysis of Freight Investments. Federal Highway Administration, Washington, 2003.

[3] Mashrur, A.; Paulin, T.; Surekha, L. An Interactive Multiobjective Decision Support Framework for Transportation Investment. Midwest Regional University Transportation Center, University of Wisconsin, Madison, 2002.

[5] Saaty, T. L. The Analytical Hierarchy Process - Planning, Priority Setting, Resource Allocation. McGraw-Hill, New York, 1980.

[6] Kim, K.; Vince, B. Application of an Analytical Hierarchy Process at the Indiana Department of Transportation for Prioritizing Major Highway Capital Investments. // Proceedings of the 7th TRB Conference on the Application of Transportation Planning Methods/ Boston, 1999, pp. 266-278.

[7] Hwang, C.; Yoon, K. Multiple Attribute Decision Making: Methods and Applications. Springer, New York, 1981. https://doi.org/10.1007/978-3-642-48318-9

[8] Zanakis, S.; Solomon, A.; Wishart, N.; Dublish,S. Multiattribute Decision Making: A Simulation Comparison of Select Methods. // European Journal of Operational Research. 107(1998), pp. 507-529. https://doi.org/10.1016/S0377-2217(97)00147-1

[9] Lu, J.; Zhang, G.; Ruan, D.; Wu, F. Multi-Objective Group Decision Making Methods, Software and Applications with Fuzzy Set Techniques. Imperial College Press, London, 2007. https://doi.org/10.1142/p505

[10] Shelton, J.; Medina, M. Integrated Multiple-Criteria Decision Making Method to Prioritize Transportation Projects. // Transportation Research Record: Journal of the Transportation Research Board. 2174 (2010), pp. 51-57. https://doi.org/10.3141/2174-08

[11] Holguin-Veras, J. Comparative Assessment of AHP and MAV in Highway Planning: Case Study. // Journal of Transportation Engineering. 121, 2(1995), pp. 191-200. https://doi.org/10.1061/(ASCE)0733-947X(1995)121:2(191)

[12] Aghdaie, M. H.; Zolfani, S.H.; Zavadskas, E.K. Prioritizing Construction Projects of Municipalities Based on AHP and COPRAS-G: A Case Study about Footbridges in Iran. // The Baltic Journal of Road and Bridge Engineering. 7, 2(2012), pp. 145-153.

https://doi.org/10.3846/bjrbe.2012.20 
[13] Behzadian, M.; Kazemzadeh, R.B.; Albadvi, A.; Aghdasi, M. PROMETHEE: A Comprehensive Literature Review on Methodologies and Applications.//European Journal of Operational Research. 200, 1(2010), pp. 198-215. https://doi.org/10.1016/j.ejor.2009.01.021

[14] Lazim, A.; Adawiyah, C. W. R. Simple Additive Weighting Methods of Multi-criteria Decision Making and Applications: A Decade Review. // International Journal of Information Processing and Management. 5, 1(2014), pp. 39-49.

[15] Kahraman, C.; Buyukozkan, G.;Ates N.Y. A Two Phase Multi- Attribute Decision Making Approach for New Product Introduction. // Information Sciences. 177, 7(2007), pp. 1567-1582 https://doi.org/10.1016/j.ins.2006.09.008

[16] Wang, T. C.; Chang, T. H. Application of TOPSIS in Evaluating Initial Training Aircraft under a Fuzzy Environment. // Expert Systems with Applications. 33(2007), pp. 870-880. https://doi.org/10.1016/j.eswa.2006.07.003

[17] Shih, H. S. Incremental Analysis for MCDM with an Application to Group TOPSIS. // European Journal of Operational Research. 186, 2(2008), pp. 720-734. https://doi.org/10.1016/j.ejor.2007.02.012

[18] Wang, X.; Triantaphyllou, E. Ranking Irregularities When Evaluating Alternatives by Using Some ELECTRE Methods. // Omega. 36(2008), pp. 45-63. https://doi.org/10.1016/j.omega.2005.12.003

[19] Tomičić-Torlaković, M.; Ćirović, G.; Mitrović, S.; Branković, V. Optimisation and Ranking of Permanent Way Types for Light Rail Systems. // Građevinar, 66, 10(2014), pp. 917-927.

[20] Opricović, S.; Tzeng, G. H. Extended VIKOR Method in Comparison With Outranking. // European Journal of Operational Research. 178, 2(2007), pp. 514-529. https://doi.org/10.1016/j.ejor.2006.01.020

[21] Triantaphyllou, E. Multi-criteria Decision Making Methods: A Comparative Study. Springer, US, 2000. https://doi.org/10.1007/978-1-4757-3157-6

[22] Marković, Lj.; Cvetković, M.; Milić-Marković, Lj. Multicriteria Decision Making When Choosing Variant Solution of Highway Route at the Level of Preliminary Design. // Facta Universitatis Series Architecture and Civil Engineering. 11, 1(2013), pp. 71-87. https://doi.org/10.2298/FUACE1301071M

[23] General Plan for the E-763 Highway Belgrade - South Adriatic, Sector III: Požega - the Montenegro Border (Boljare), Book 6: Evaluation and Ranking of the Corridor Variants. Institute of Transportation CIP, Serbia, 2007. (in Serbian)

\section{Authors' addresses}

Ljubo Marković, PhD, Associate Professor

Faculty of Technical Sciences

Kneza Miloša 7, 38220 Kosovska Mitrovica, Republic of Serbia

E-mail: ljmarkovic@open.telekom.rs

Ljiljana Milić Marković, PhD, Chief Project Manager CeS.COWI d.o.o,

Južni Bulevar 1a, 11000 Belgrade, Republic of Serbia

E-mail:1jmm@cescowi.rs

Snežana Mitrović, PhD, Professor

The Belgrade University

College of Civil Engineering and Geodesy

Hajduk Stankova 2, 11000 Belgrade, Republic of Serbia

E-mail: mitrozs@sezampro.rs

Slobodan Stanarević, MSc in Civil Engineering

General Manager of "Civil Engineering Institute IG"

Kralja Petra I. Karađorđevića 92-98, 78000 Banja Luka,

Republic of Srpska, Bosnia and Herzegovina

E-mail: sss@institutig.com 